\title{
Glacier mass balance interpreted from biological analysis of firn cores in the Chilean lake district
}

\author{
P. SANTIBAÑEZ, ${ }^{1}$ S. KOHSHIMA, ${ }^{2}$ R. SCHEIHING,${ }^{1,3}$ J. JARAMILLO ${ }^{4}{ }^{1}$ T. SHIRAIWA, ${ }^{5}$ \\ S. MATOBA, ${ }^{6}$ D. KANDA, ${ }^{7}$ P. LABARCA, ${ }^{1}$ G. CASASSA ${ }^{1}$ \\ ${ }^{1}$ Centro de Estudios Científicos, Av. Arturo Prat 514, Casilla 1469, Valdivia, Chile \\ E-mail: psantibanez@cecs.cl \\ ${ }^{2}$ Wildlife Research Center, Kyoto University, JASSO bldg 3F, 2-24 Tanaka-Sekiden-cho, Sakyo-ku, Kyoto 606-8203, Japan \\ ${ }^{3}$ Escuela de Graduados, Facultad de Ciencias, Universidad Austral de Chile, Casilla 567, Valdivia, Chile \\ ${ }^{4}$ Instituto de Botánica, Facultad de Ciencias, Universidad Austral de Chile, Casilla 567, Valdivia, Chile \\ ${ }^{5}$ Research Institute for Humanity and Nature, Kita-ku, Kyoto 603-847, Japan \\ ${ }^{6}$ Institute of Low Temperature Science, Hokkaido University, Sapporo 060-0819, Japan \\ ${ }^{7}$ National Institute of Polar Research, Kaga 1-9-10, Itabashi-ku, Tokyo 173-8515, Japan
}

\begin{abstract}
The first analyses of biological components in glaciers of the Chilean lake district are presented based on microalgae biovolume, pollen and other microorganisms detected in shallow $(\sim 10 \mathrm{~m})$ firn/ice cores. Three cores were retrieved, two at Volcán Mocho-Choshuenco $\left(39^{\circ} 55^{\prime} \mathrm{S}\right.$, $72^{\circ} 02^{\prime} \mathrm{W}$; summit at $2422 \mathrm{~m}$ a.s.l; east glacier at $2000 \mathrm{~m}$ a.s.l.), and one at the summit of Volcán Osorno $\left(41^{\circ} 06^{\prime} \mathrm{S}, 72^{\circ} 30^{\prime} \mathrm{W} ; 2652 \mathrm{~m}\right.$ a.s.l.). Microalgae, protozoa and pollen quantified in the samples obtained from the two summit cores show clear fluctuations interpreted as seasonal signs. In contrast, $\delta D$ and many chemical species from the summit cores show strong dampening at depth, probably due to water percolation. The limited information provided by isotopic and chemical analyses is used to support the seasonal interpretation of biological parameters from the summit cores, with microorganism maxima inferred to occur in summer and pollen maxima in spring. A good comparison is found between massbalance estimations from the Volcán Mocho-Choshuenco summit core and values obtained near that site by means of the stake method. It is concluded that biological analyses of firn/ice cores provide reliable estimations of annual and seasonal markers from these temperate glaciers.
\end{abstract}

\section{INTRODUCTION}

Ice cores from Greenland and Antarctica have provided crucial evidence with which to reconstruct the environmental and climatic past in polar regions (e.g. Alley and others, 1995; McManus, 2004). To complement information obtained in these regions, it is essential to study ice cores in low- and mid-latitude glaciers. Although these cores cover shorter timescales, they contribute unique information on local and regional conditions (e.g. Thompson and others, 2000, 2003).

Low- and mid-latitude glaciers are generally temperate, and traditional methods used in polar ice cannot normally be used for characterizing the stratigraphy and dating ice cores from these glaciers since annual and seasonal signals of stable isotopes and chemical species are strongly disturbed due to melt and percolation (Schwikowski and others, 1999b; Eichler and others, 2001; Pohjola, 2002; Olivier and others, 2003). Other methods of characterizing and dating ice cores from temperate glaciers are therefore needed.

The study of microorganisms living on temperate glaciers can provide a novel, robust method for ice-core analysis. Dating of temperate ice cores has been performed previously by analysis of snow algae, such as on Yala glacier, Nepal Himalaya (Yoshimura and others, 2000); Glaciar Tyndall, Hielo Patagónico Sur (southern Patagonia icefield) (Shiraiwa and others, 2002; Kohshima and others, 2007); and Sofiyskiy glacier, Russian Altai, where other biological components such as pollen and fungi have also been studied
(Uetake and others, 2006). These investigations together with other studies of algal communities at the glacier surface concluded that snow algae are a useful seasonal marker for ice-core dating, reconstruction of past climate and environmental conditions, and assessment of past annual mass balance at low/mid-latitudes and low altitudes (e.g. Yoshimura and others, 1997; Takeuchi and others, 1998; Takeuchi, 2001; Kohshima and others, 2002; Takeuchi and Kohshima, 2004).

Snow algae grow in the snow and ice during the melt season. They are well preserved in ice cores, as their size is larger than that of chemical species and isotopes, and are therefore less affected by percolation (Yoshimura and others, 2000; Kohshima and others 2002; Shiraiwa and others, 2002; Uetake and others, 2006). Because of their size $(<30 \mu \mathrm{m})$, they are called microalgae hereafter.

Besides microalgae, various organisms have been found on the surface of several glaciers, such as insects, copepods, fungi, cyanobacteria and bacteria (Kohshima, 1984; Takeuchi, 2001; Segawa and others, 2005; Uetake and others, 2006). This ecosystem is relatively simple and closed, comparable to other freshwater environments such as lakes and rivers where microalgae support heterotrophic populations (Kohshima, 1987; Kohshima and others, 2002).

New and alternative methods for dating temperate glaciers have focused on pollen seasonally dispersed on glaciers. For example, seasonal and annual markers have been detected based on pollen signals from ice cores from the Altai (Nakazawa and others, 2004, 2005). Pollen can also be a sensitive indicator of past atmospheric circulation, 

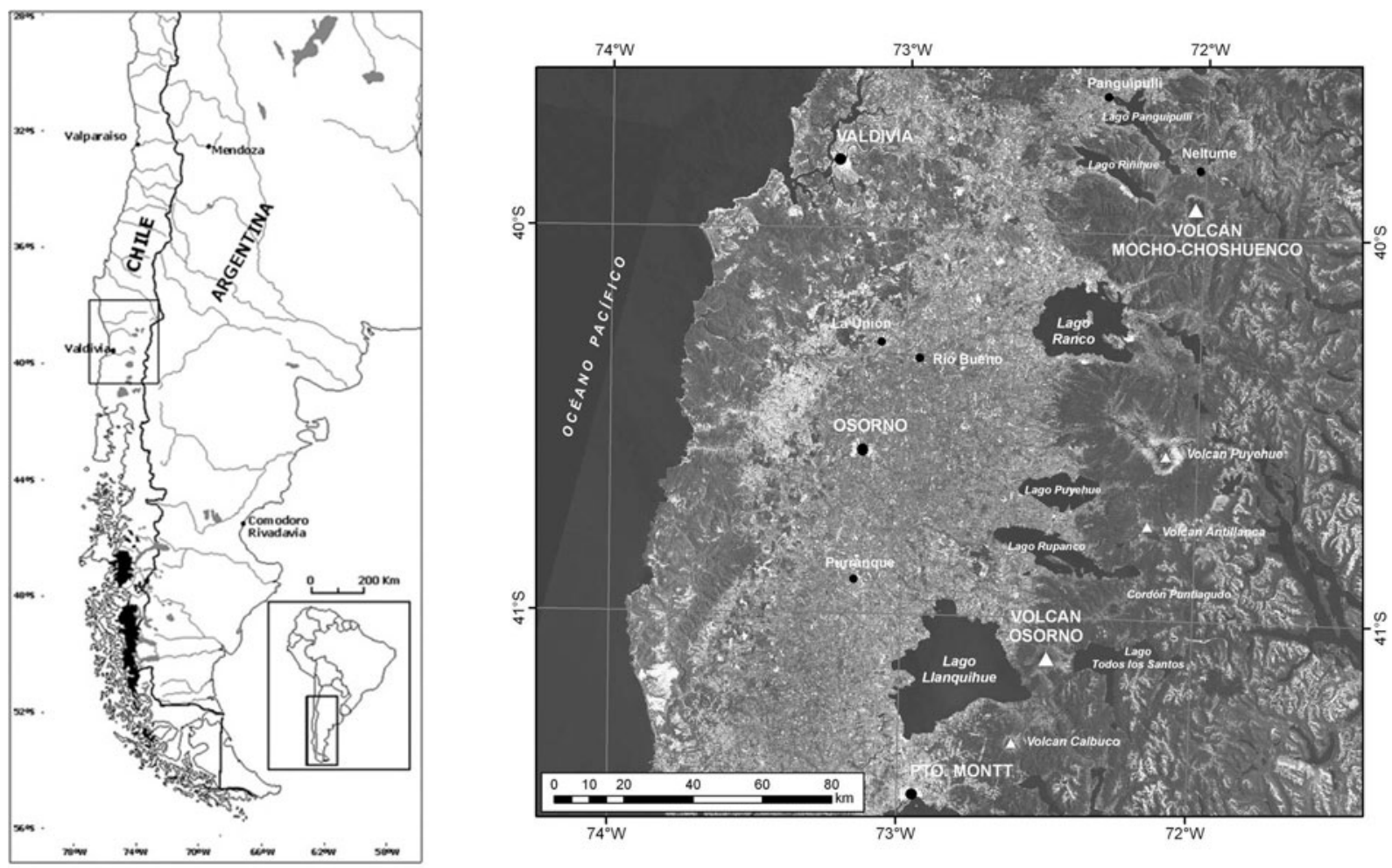

Fig. 1. Location of Volcán Mocho-Choshuenco and Volcán Osorno in the Chilean lake district.

being a valuable proxy for understanding the climatic and environmental past in polar and non-polar regions (Liu and others, 1998; Bourgeois and others, 2000; Nakazawa and others, 2004, 2005).

To improve the reliability of ice-core dating, multiple information sources are clearly beneficial, such as pollen and microalgae (Uetake and others, 2006). Furthermore, microorganisms growing on the glacier can also provide information on past environmental conditions, such as temperature and snow accumulation, which affect their growth (Yoshimura and others, 2000; Kohshima and others, 2002).

The objective of this study is to date, by means of biological analyses, three shallow firn cores $(\sim 10 \mathrm{~m})$ retrieved from temperate glaciers in the Andes of the Chilean lake district. In addition to biological analyses, the preservation of chemical and isotopic records and physical properties is evaluated in order to date the ice cores with seasonal and annual resolution, and attempt to estimate the mass balance at each location. This study is also expected to aid in the selection of an appropriate site for obtaining a future deep ice core in the region $(>50 \mathrm{~m})$ which could provide a unique climatic and environmental record from mid-latitudes in the Southern Hemisphere.

\section{MATERIALS AND METHODS}

\section{Firn/ice core drilling and site description}

Three firn cores were retrieved from glaciers located on volcanoes in the lake district of the Cordillera de los Andes, Chile (Fig. 1). At Volcán Mocho-Choshuenco (3955'S, $72^{\circ} 02^{\prime} \mathrm{W}$ ), one $10.0 \mathrm{~m}$ long core was drilled at $2000 \mathrm{~m}$ a.s.l. on the southeast glacier on 26 October 2005, and one $10.2 \mathrm{~m}$ long firn core was drilled the following day at $2422 \mathrm{~m}$ a.s.l. on the summit. On 1 November 2005, a $10.4 \mathrm{~m}$ long core was drilled on the summit of Volcán Osorno $\left(41^{\circ} 06^{\prime} \mathrm{S}\right.$, $72^{\circ} 30^{\prime} \mathrm{W} ; 2652 \mathrm{~m}$ a.s.I.). The thickness and position of ice lenses were recorded and firn/ice density was measured immediately after drilling.

Both volcanoes are active, the last eruptions having occurred in 1864 at Volcán Mocho-Choshuenco and in 1869 at Volcán Osorno (González-Ferrán, 1995). Both volcano summits are ice-filled calderas with relatively flat surfaces. The glaciological characteristics of Volcán MochoChoshuenco are well documented since 2003 as a result of a regular mass-balance monitoring programme (Rivera and others, 2005). The volcano summit altitudes were thought to be high enough to preserve some of the chemical and biological signals deposited on the glaciers. In fact, the mean annual temperature of coastal stations at latitudes similar to that of the volcanoes is $\sim 11^{\circ} \mathrm{C}$. Assuming a vertical lapse rate of $6^{\circ} \mathrm{C} \mathrm{km}^{-1}$, the expected mean annual temperature at the summit of the volcanoes should be -3 to $-5^{\circ} \mathrm{C}$. However, the presence of melt layers and thick ice lenses on the surface and in shallow pits detected during the glacier mass-balance measurements indicated that meltwater-related post-depositional processes might be relevant. Additionally, release of latent heat during refreeze periods can raise the firn/ice layer temperature to the melting point, and in fact these glaciers might be of temperate nature. Enhanced geothermal heat in this active volcanic region might also contribute to raising the ice temperature through thermal conductivity at the glacier bed, although there are no data to sustain this.

Volcán Mocho-Choshuenco and Volcán Osorno are stratovolcanoes approximately $20 \mathrm{~km}$ in diameter, composed of layers of lavas and pyroclasts and a summit caldera with a nested pyroclastic cone in the centre (Echegaray, 2000). These volcanic rocks were generated through a long sequence of various kinds of eruptions with ages ranging from early Pleistocene to late Holocene (AD 1864), 


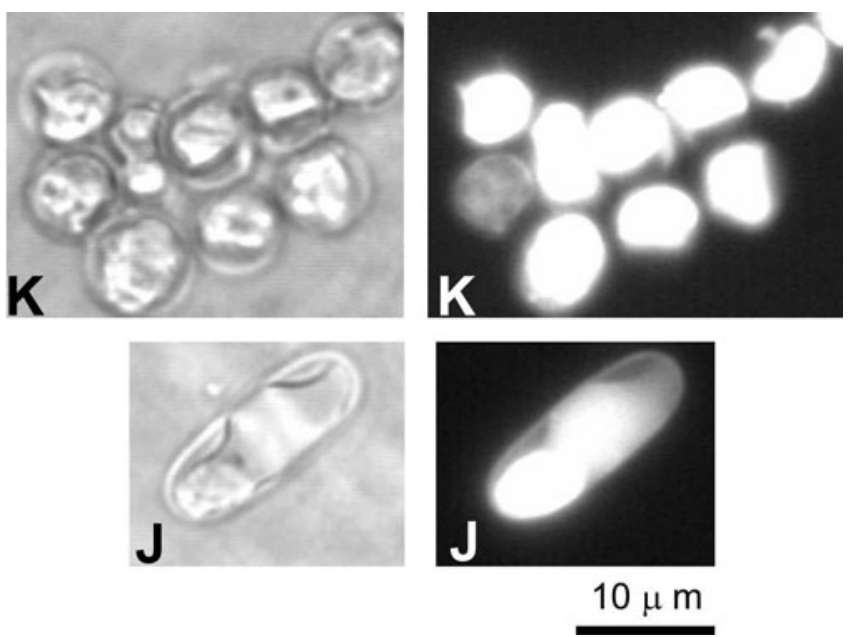

Fig. 2. Largest biovolume morphotypes ( $\mathrm{K}$ and $\mathrm{J}$ ) of microalgae observed in the Volcán Osorno summit core. The photos on the left were acquired under a normal light microscope; those on the right under an Olympus BX-FLA fluorescence microscope.

corresponding mainly to lavas and in a minor proportion to pyroclasts, with an andesitic-basaltic to dacitic composition (Echegaray, 2000). The regional geological composition beyond the volcanic cones shows the presence of a variety of formations, including sedimentary, metamorphic, volcanic and intrusive rocks, with ages ranging from Upper Carboniferous to Quaternary.

\section{Sample processing}

On the glacier the firn/ice core samples were cut with a precleaned stainless-steel knife into $20 \mathrm{~cm}$ sections, scraping off a $1 \mathrm{~cm}$ section of the core surface to eliminate possible contaminants. The samples were packed into pre-cleaned plastic bags and later melted at room temperature in a laboratory at Centro de Estudios Científicos (CECS), Valdivia, Chile, each sample being bottled in two clean plastic containers of $50 \mathrm{~mL}$ each. All samples were then immediately stored in a freezer at $-20^{\circ} \mathrm{C}$. One bottle was used for biological analysis, and the other was sent to Japan for analyses of stable isotopes and chemical species.

\section{Sample analysis}

In the biological analyses performed at CECS, the samples were mounted and fixed inside a laminar-flow table. Filtering of $15 \mathrm{~mL}$ samples was performed using hydrophilic polytetrafluoroethylene (PTFE) membrane filters (JHWP013000: $0.2 \mu \mathrm{m}$ pore size, $13 \mathrm{~mm}$ diameter; Millipore, USA). Each filter was mounted and fixed in glycerol, formalin and water solution (1:1:1 volume) on a glass slide under cover-slip.

Counts of microorganisms and pollen grains were made with a fluorescent microscope (Olympus BX-FLA). The total cell number of microalgae and pollen of Nothofagus spp. was estimated on each filter by counting the cells along three to five parallel transects. In the case of Podocarpaceae, all pollen grains were counted within the filter. For protozoa the cell number was estimated along nine parallel transects across the filter.

The algae cells were classified according to their morphotypes, which correspond to microalgae showing the same morphological and size characteristics. Each morphotype was assigned a capital letter. Mean cell volume was estimated by measuring the size of $50-100$ cells for each morphotype, classifying their sizes in intervals of $1 \mu \mathrm{m}$. Algal biovolume was determined using the technique developed by Lohmann (1908), Yoshimura and others $(1997,2000)$ and Hillebrand and others (1999). Microalgae smaller than $5 \mu \mathrm{m}$ were eliminated in the algal biovolume results shown in the profiles, as suggested by Uetake and others (2006).

Pollen density was recorded according to the technique described in Nakazawa and others (2004, 2005). The work of Heusser (1971) and expert advice (personal communication from P. Moreno, 2006) were used for pollen identification.

Two control runs with five replicas each were performed to check for possible sources of contamination in the method. One control run used nanopure water frozen in bottles during a period of 1 week, and the other control run used nanopure water frozen during 1 month. The control runs were mounted, fixed and counted using the same method as for the samples.

Major ions of $\mathrm{Na}^{+}, \mathrm{Ca}^{2+}, \mathrm{K}^{+}, \mathrm{NH}_{4}{ }^{+}, \mathrm{NO}_{3}{ }^{-}, \mathrm{Mg}^{2+}, \mathrm{SO}_{4}{ }^{2-}$ and $\mathrm{Cl}^{-}$and stable isotopes of $\delta \mathrm{D}$ were analyzed at the Institute of Low Temperature Science, Hokkaido University, Japan, using ion chromatography and mass spectrometry (Schwikowski and others, 1999a, b; Shiraiwa and others, 2002). The analysis of chemical species was not performed for the core drilled at 2000 ma.s.l. on Volcán MochoChoshuenco.

\section{RESULTS AND DISCUSSION \\ Organisms and pollen observed in the ice-core samples}

Microalgae, protozoa, copepods and pollen grains in icecore samples are described for the three cores.

\section{Microalgae}

Twenty-seven morphotypes of microalgae were observed in the ice core from Volcán Osorno. Twenty-five belong to Division Chlorophyta, and two to Division Cyanophyta. Maximum biovolume in the ice core is $19.9 \times 10^{4} \mu \mathrm{m}^{3} \mathrm{~mL}^{-1}$ at $6 \mathrm{~m}$ depth, $\mathrm{K}$ and $\mathrm{J}$ being the largest biovolume morphotypes in this layer (Fig. 2).

Twenty-two morphotypes of microalgae were observed in the ice core from the summit of Volcán Mocho-Choshuenco. Twenty-one are from Division Chlorophyta, and one from Division Cyanophyta. Maximum biovolume in the ice core is $5.6 \times 10^{4} \mu \mathrm{m}^{3} \mathrm{~mL}^{-1}$ at $7 \mathrm{~m}$ depth, $\mathrm{N}, \mathrm{K}$ and FA being the largest biovolume morphotypes at this depth (Fig. 3).

Seventeen morphotypes of microalgae were observed in the ice core from 2000 ma.s.l. at Volcán MochoChoshuenco. Sixteen are from Division Chlorophyta, and one from Division Cyanophyta. Maximum biovolume in the ice core is $1.4 \times 10^{3} \mu \mathrm{m}^{3} \mathrm{~mL}^{-1}$.

Algal biovolume values from the volcano summits are similar to those reported in other studies of ice cores such as at Yala glacier (Yoshimura and others, 2000), Glaciar Tyndall (Shiraiwa and others, 2002; Kohshima and others, 2007) and Sofiyskiy glacier (Uetake and others, 2006).

\section{Protozoa}

Undescribed species of protozoa (Santibáñez, 2007) were found in the cores from Osorno and Mocho-Choshuenco volcanoes. These were used as an additional tool for 
biological interpretation. These protozoa were confirmed to live on the glacier, as was inferred from observation of individuals present in the samples which showed undigested food inside the testa and also signals of reproduction.

Maximum protozoa abundance was 3 individuals $\mathrm{mL}^{-1}$ in the Volcán Osorno core, 38 individuals $\mathrm{mL}^{-1}$ in the MochoChoshuenco summit core and 1.6 individuals $\mathrm{mL}^{-1}$ in the Mocho-Choshuenco $2000 \mathrm{~m}$ core.

\section{Copepods}

Small copepods of about $800 \mu \mathrm{m}$ in body length, and a nauplius (larval stage) of about $100 \mu \mathrm{m}$ in body length, were observed in the bottom ice layer of the Volcán MochoChoshuenco $2000 \mathrm{~m}$ core. This finding suggests that copepods live and reproduce on the glacier. The morphology of this copepod is close to that of the copepod species living in the snow and ice of a Himalayan glacier as reported by Kikuchi (1994).

\section{Pollen}

Podocarpaceae and genus Nothofagus spp. (Fig. 4) are the most abundant in all cores. The presence of these pollen types is in agreement with the predominant trees growing in the surrounding Valdivian forest and the anemophilian characteristics shown by both types of pollen. Flowering timing of genus Nothofagus depends on each species, with periods between August and December (Riveros and SmithRamirez, 1995; Riveros and others, 1995; Riveros and others, 2003; Hechenleitner and others, 2005). Podocarpaceae family members flower between November and January (Hechenleitner and others, 2005). The flowering period of tree species occurs later at higher altitudes, continuing until late summer in some cases (personal communication from P. Moreno, 2006).

Pollen peaks of Podocarpaceae and Nothofagus are absent in some layers estimated to correspond to springsummer from biological profiles at Osorno and MochoChoshuenco volcanoes. Previous data show that pollen deposits on the surface of tropical glaciers from the Andean altiplano in Bolivia and Peru present significant spatial and temporal variations, showing differences in pollen concentration and percentage at the same sites, and between two consecutive years (Reese and others, 2003; Reese and Liu, 2005). If relevant temporal and/or spatial variations occur in pollen, due to either source or post-depositional processes, this dating method becomes unreliable (Nakazawa and others, 2005). Therefore, knowledge of the spatial and/or temporal variability of pollen on the glacier surface is needed before it is validated as a reliable seasonal or annual record. Consequently, the absence of pollen peaks in some summer-spring layers interpreted from microalgae and protozoa does not necessarily connote periods without pollen dispersal.

Maximum Podocarpaceae pollen concentration in the Volcán Osorno core is 1.47 grains $\mathrm{mL}^{-1}$, and maximum Nothofagus spp. pollen concentration is 0.74 grains $\mathrm{mL}^{-1}$. In the Volcán Mocho-Choshuenco summit core, maximum Podocarpaceae pollen concentration is 0.93 grains $\mathrm{mL}^{-1}$ and maximum Nothofagus spp. pollen concentration is 0.41 grains $\mathrm{mL}^{-1}$. For the Mocho-Choshuenco $2000 \mathrm{~m}$ core, maximum Podocarpaceae pollen concentration is 1.8 grains $\mathrm{mL}^{-1}$ and maximum Nothofagus spp. pollen concentration is 0.2 grains $\mathrm{mL}^{-1}$.
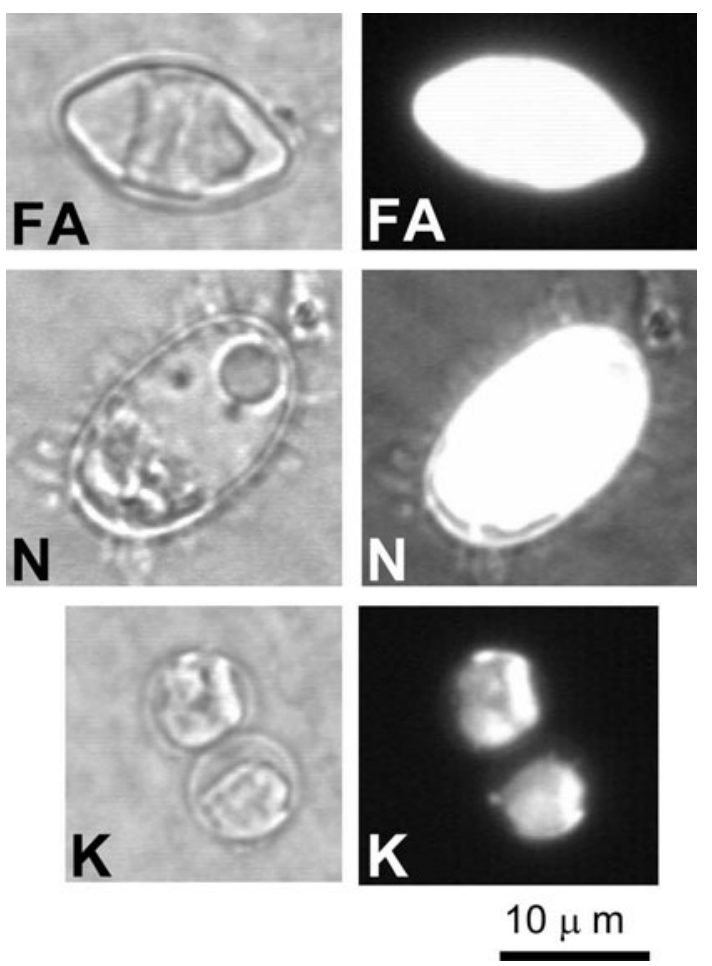

Fig. 3. Largest biovolume morphotypes (FA, N and $\mathrm{K}$ ) of microalgae observed in the Volcán Mocho-Choshuenco summit core. The photos on the left were taken under a light microscope; those on the right under an Olympus BX-FLA fluorescence microscope.

\section{Volcán Osorno core analysis}

Variations in the biological profile, physical properties, $\delta \mathrm{D}$ and ion chemistry

The vertical profiles of microorganisms show preserved fluctuations at Volcán Osorno (Fig. 5). The vertical algal biovolume shows two peaks at 5.6-7.2 $\mathrm{m}$ and $8.2-10.0 \mathrm{~m}$ that are interpreted as corresponding to the meltwater season. These levels are in agreement with those with maximum protozoa abundance.

A Podocarpaceae-rich layer appears within the surface layer from 0 to $1 \mathrm{~m}$, and a Nothofagus-rich layer appears from 0 to $0.5 \mathrm{~m}$ in depth (Fig. $5 \mathrm{c}$ and d). This surface layer is interpreted as corresponding to the pollen dispersal season, which agrees with the core-drilling date (1 November 2005). The surface layer does not show a microalgae layer, which suggests that during the core drilling the microalgae did not yet have adequate living conditions on the glacier surface. This agrees with Yoshimura and others $(1997,2000)$ who indicated that microalgal growth in the Himalaya starts at the beginning of summer and continues throughout the season. Neither are protozoa observed in this surface layer, probably for the same reason as for the microalgae.

A Podocarpaceae pollen signal is observed at the bottom of the core, between 10.2 and $10.4 \mathrm{~m}$. This suggests pollen dispersion within this layer, interpreted as corresponding to the flowering season (spring-summer), which terminates at $8.2 \mathrm{~m}$ (late summer-early autumn) according to the microalgae profile.

Fluctuations in $\delta \mathrm{D}$ are observed within the upper $5 \mathrm{~m}$ section of the core (Fig. 5h). Based on the biological profiles, the layer from 1 to $5.4 \mathrm{~m}$ is interpreted as corresponding to the accumulation period autumn-winter 2005. In fact this layer preserves variations in $\delta \mathrm{D}$ signals. Below $5 \mathrm{~m}$ the 

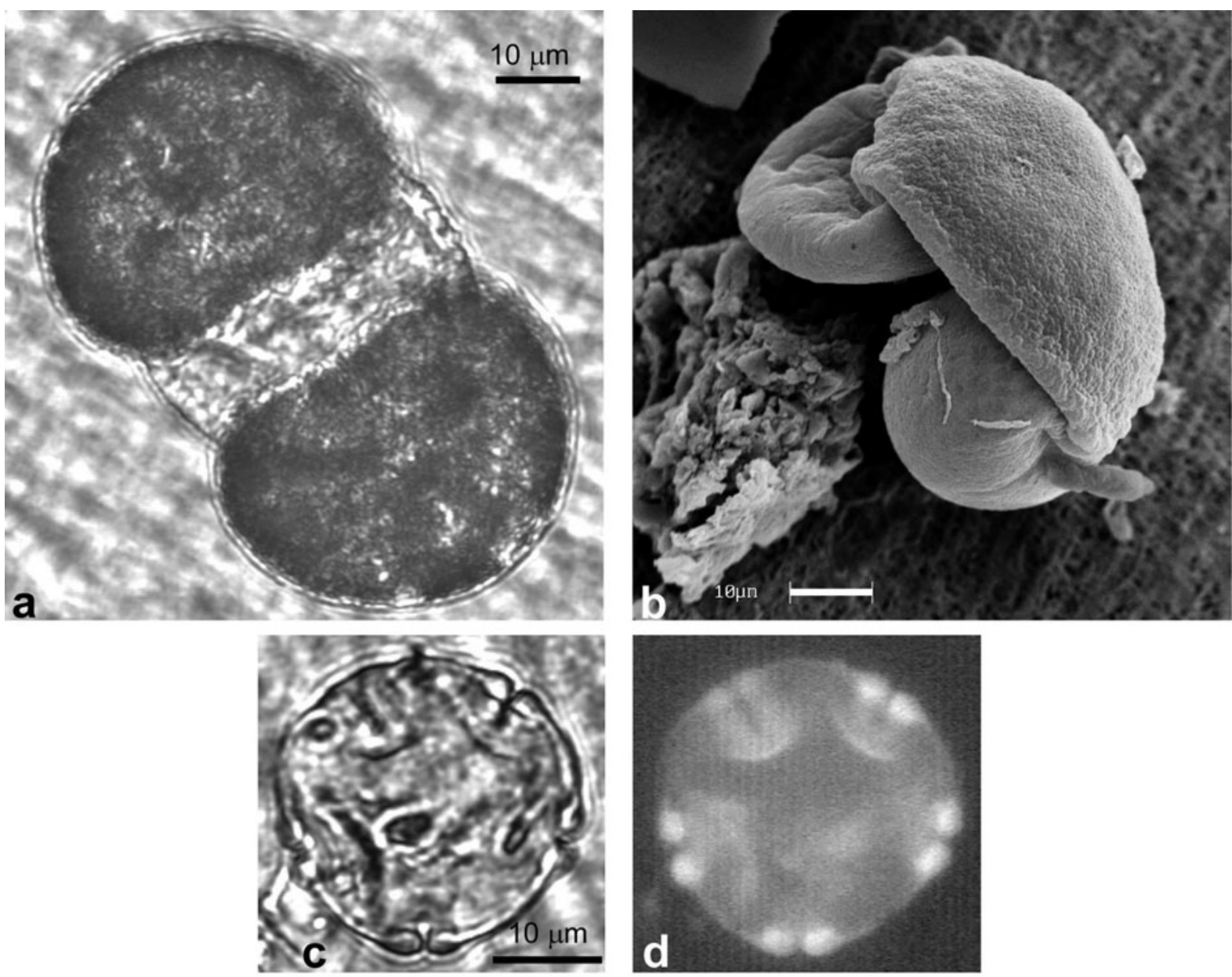

Fig. 4. Pollen observed in the Volcán Osorno and Volcán Mocho-Choshuenco cores: (a, b) Podocarpaceae pollen; and (c, d) Nothofagus spp. pollen. Photos (a) and (c) were taken under a light microscope, (d) under an Olympus BX-FLA fluorescence microscope, and (b) under a scanning electron microscope.

fluctuations in $\delta \mathrm{D}$ are strongly damped, suggesting an important effect due to water percolation, consistent not only with a maximum percentage of ice lenses at $6 \mathrm{~m}$, but also with an algae and protozoa maximum at the same depth. Hence, the layer between 5.4 and $7.2 \mathrm{~m}$ is interpreted as corresponding to summer 2004/05. Consequently, the $\delta D$ record cannot be used to date firn layers of previous years.

Ice layers are almost absent at $1.8-4.6 \mathrm{~m}$ and $7.6-8.4 \mathrm{~m}$ (Fig. 5e), indicating reduced melt and refreeze. These horizons are interpreted as corresponding to autumn-winter as suggested by the biological profiles. Contrastingly, a high percentage of ice layers are observed within the horizons interpreted as spring 2005, summer 2004/05 and summer 2003/04 (Fig. 5e), suggesting relevant melt-freeze periods

Table 1. Median concentrations (ppb) of chloride, sodium, potassium and sulphate in winter and summer snow for the Volcán Osorno core samples, along with the summer/winter ratio

\begin{tabular}{lccccc}
\hline & $n$ & $\mathrm{Cl}^{-}$ & $\mathrm{Na}^{+}$ & $\mathrm{K}^{+}$ & $\mathrm{SO}_{4}{ }^{2-}$ \\
\hline Winter & 28 & 267.6 & 162.3 & 6.9 & 40.8 \\
Summer & 23 & 169.4 & 101.6 & 4.5 & 15.9 \\
Ratio & & 1.5 & 1.6 & 1.5 & 2.5 \\
\hline
\end{tabular}

during the melt season in this area. The density profile (Fig. 5f) shows an increase from $0.5 \mathrm{~g} \mathrm{~cm}^{-3}$ to nearly $0.7 \mathrm{~g} \mathrm{~cm}^{-3}$ at depth, with values approaching the ice density according to the presence of ice lenses. The firn-ice transition was not reached and must occur below $10.4 \mathrm{~m}$.

Fluctuations in $\mathrm{Cl}^{-}, \mathrm{Na}^{+}, \mathrm{K}^{+}$and $\mathrm{SO}_{4}{ }^{2-}$ concentrations show near-zero values in layers interpreted as summer 2004/ 05 and summer 2003/04, and high values in layers interpreted as autumn-winter 2005 and autumn-winter 2004 (Fig. 5; Table 1). High levels of $\mathrm{Cl}^{-}, \mathrm{Na}^{+}, \mathrm{K}^{+}$and $\mathrm{SO}_{4}{ }^{2-}$ are also observed in the surface layer corresponding to spring 2005, suggesting that the dampening of chemical signals during summer is due to post-depositional processes, probably related to partial meltwater percolation. The high surface levels observed during drilling suggest that melt and percolation effects are still insignificant.

Concerning $\mathrm{Ca}^{2+}$ and $\mathrm{Mg}^{2+}$, a maximum value corresponding to autumn-winter 2004 is observed, which does not occur in the autumn-winter 2005 layer. $\mathrm{NO}_{3}{ }^{-}$and $\mathrm{NH}_{4}{ }^{+}$ show maximum values in the upper layer corresponding to spring 2005, while seasonal variations are absent below this layer, suggesting that percolation or other post-depositional processes are relevant.

The site shows dominant concentrations of $\mathrm{Cl}^{-}$and $\mathrm{Na}^{+}$ (Table 2), pointing to a dominance of natural constituents, which frequently correspond to sea spray (Olivier and others 2003; Eichler and others, 2004). Concentrations of ions of 
Table 2. Ion median concentrations of all samples in the Volcán Osorno core

\begin{tabular}{ll}
\hline & $\begin{array}{c}\text { Median } \\
\mu \mathrm{EqL} \mathrm{L}^{-1}\end{array}$ \\
\hline Anions & \\
$\mathrm{Cl}^{-}$ & 5.50 \\
$\mathrm{SO}_{4}{ }^{2-}$ & 0.65 \\
$\mathrm{NO}_{3}{ }^{-}$ & 0.11 \\
$\mathrm{Cations}^{+}$ & \\
$\mathrm{Na}^{+}$ & 5.01 \\
$\mathrm{Ca}^{2+}$ & 3.28 \\
$\mathrm{NH}_{4}{ }^{+}$ & 1.11 \\
$\mathrm{Mg}_{2}^{+}$ & 0.44 \\
$\mathrm{~K}^{+}$ & 0.16 \\
\hline
\end{tabular}

anthropogenic origin (e.g. $\mathrm{NO}_{3}{ }^{-}, \mathrm{NH}_{4}{ }^{+}$and $\mathrm{SO}_{4}{ }^{2-}$ ) are even lower here than pre-industrial values from cores of the European Alps (Schwikowski and others, 1999a) (Table 2).

Sea-salt aerosol contribution of chemical species is important at this site, as demonstrated by: (1) the high correlation coefficient between $\mathrm{Cl}^{-}$and $\mathrm{Na}^{+}(r=0.998$; Table 3); (2) the proximity of the $\mathrm{Cl}^{-} / \mathrm{Na}^{+}$proportion, $1.11 \pm 0.7$, obtained in this study (Fig. $5 g$; Table 2) to the marine reference value of 1.16 (Keene and others 1986); and (3) the fact that other chemical species that are sea-salt constituents (e.g. $\mathrm{Cl}^{-}, \mathrm{Ca}^{2+}, \mathrm{Na}^{+}, \mathrm{Mg}^{2+}, \mathrm{K}^{+}$and $\mathrm{SO}_{4}{ }^{2-}$ (Watanabe and others, 2003)) show high correlation coefficients at this site (Table 3 ). This finding is not surprising since the drilling area is $\sim 100 \mathrm{~km}$ east of the Pacific Ocean, under the influence of the predominant westerly circulation.

\section{Estimation of mass balance}

Firn density data indicate that this ice core of $10.4 \mathrm{~m}$ corresponds to $5.88 \mathrm{~m}$ w.e. According to the profiles of microalgae, protozoa, pollen and chemical species (Fig. 5), it is estimated that the $10.4 \mathrm{~m}$ core includes one annual layer from 2004/05 and a layer from the last accumulation period of autumn-winter 2005. The net mass balance from autumn 2004 to autumn 2005 is $1.51 \mathrm{~m}$ w.e., and the winter balance is $2.4 \mathrm{~m}$ w.e. Considering a rainfall amount of $1189 \mathrm{~mm}$ between 1 April and 31 October 2005 (personal communication from J. Carrasco, 2007) for the coastal station Puerto Montt ( $100 \mathrm{~km}$ southwest of the drilling site), our autumnwinter mass-balance estimation shows that the Volcán Osorno accumulation preserved in mid-spring 2005 was twice as much as the autumn-winter-early-spring precipitation recorded at Puerto Montt, which is reasonable considering the strong orographic effect associated with the westerly airflow across the southern Andes. Available data for the mountain station Punta Huano (200 ma.s.I.; located $75 \mathrm{~km}$ northeast of Puerto Montt and $70 \mathrm{~km}$ southwest of Volcán Osorno) show an annual precipitation of $3095 \mathrm{~mm}$ (personal communication from J. Carrasco, 2007). In contrast, the annual accumulation preserved in 2004/05 in the Volcán Osorno core is similar to the annual precipitation of $1621 \mathrm{~mm}$ recorded at Puerto Montt between April 2004 and March 2005 (personal communication from J. Carrasco, 2007), which can be explained by the strong melt that is responsible for the ablation of an important autumn-winterearly-spring layer during summer.
Table 3. Correlation matrix of the Volcán Osorno chemical species, taken as the logarithmic values of concentrations. The underlined numbers are correlation coefficients larger than 0.8 , and the bold numbers are correlation coefficients larger than 0.7

\begin{tabular}{lccccccc}
\hline & $\mathrm{Cl}^{-}$ & $\mathrm{Na}^{+}$ & $\mathrm{Ca}^{2+}$ & $\mathrm{Mg}^{2+}$ & $\mathrm{K}^{+}$ & $\mathrm{SO}_{4}{ }^{2-}$ & $\mathrm{NO}_{3}{ }^{-}$ \\
\hline $\mathrm{Na}^{+}$ & $\underline{\mathbf{1 . 0 0}}$ & & & & & & \\
$\mathrm{Ca}^{2+}$ & 0.44 & 0.45 & & & & & \\
$\mathrm{Mg}^{2+}$ & $\underline{\mathbf{0 . 8 1}}$ & $\underline{\mathbf{0 . 8 0}}$ & 0.68 & & & & \\
$\mathrm{~K}^{+}$ & 0.62 & $\mathbf{0 . 6 4}$ & $\mathbf{0 . 7 3}$ & $\mathbf{0 . 7 4}$ & & & \\
$\mathrm{SO}_{4}{ }^{2-}$ & $\mathbf{0 . 7 3}$ & $\mathbf{0 . 7 3}$ & $\mathbf{0 . 7 5}$ & $\underline{\mathbf{0 . 8 6}}$ & $\underline{\mathbf{0 . 8 5}}$ & & \\
$\mathrm{NO}_{3}{ }^{-}$ & 0.44 & 0.45 & $\mathbf{0 . 7 5}$ & 0.65 & $\mathbf{0 . 7 2}$ & $\underline{\mathbf{0 . 8 6}}$ & \\
$\mathrm{NH}_{4}{ }^{+}$ & 0.31 & 0.32 & 0.46 & 0.29 & 0.57 & 0.42 & 0.45 \\
\hline
\end{tabular}

\section{Volcán Mocho-Choshuenco summit core analysis}

Variations in the biological profile, physical properties, $\delta \mathrm{D}$ and ion chemistry

Similar to the case of the Volcán Osorno core, the biological species preserved in the Mocho-Choshuenco summit core also show variations which are interpreted as seasonal markers (Fig. 6). The microalgae and protozoa peaks show four layers at 5.4-6.4, 6.8-7.4, 7.6-8.4 and 8.6-9.2 $\mathrm{m}$ which are interpreted as summer melt seasons. A microalgae peak observed between 4.2 and $4.4 \mathrm{~m}$, which shows a smaller biovolume than in the other layers, is inferred not to represent a summer melt season, due to protozoa and pollen absence and lack of correlation with chemical and deuterium profiles (Fig. 6). One possibility is that this weak peak is due to wind transport (Müller and others, 2001) from microalgae sources located in nearby $(\sim 30-60 \mathrm{~km})$ lake sites.

In both pollen profiles, a signal is observed in the surface layer between 0 and $1.5 \mathrm{~m}$ which is interpreted as corresponding to spring 2005. The absence of microalgae and protozoa in this period agrees with data from the Volcán Osorno core and with the observation by Yoshimura and others $(1997,2000)$ concerning the initial date of algal bloom.

When comparing the microorganism data with those from Podocarpaceae records, three layers interpreted as corresponding to the summer melt season are observed to coincide, with two of those layers coinciding with Nothofagus spp. horizons. Similar to the case of Volcán Osorno, the absence of pollen layers does not necessarily indicate absence of melt, so the information provided by pollen is regarded as confirming the interpretation of the microorganism record.

Two horizons without ice layers are recognized: 0-5.4 m and 5.6-6.8 $\mathrm{m}$ (Fig. 6e). When comparing these depths to the biological profiles, the first horizon below $1.5 \mathrm{~m}$ is interpreted as corresponding to autumn-winter, with no microorganisms or pollen. In contrast, the 5.6-6.8 m horizon coincides with a layer of microalgae, protozoa and pollen, which is located between two layers with $100 \%$ ice. The ice layer at $5.4 \mathrm{~m}$ shows a sudden density increase from 0.55 to $0.77 \mathrm{~g} \mathrm{~cm}^{-3}$ (Fig. 6f) and an accompanying dampening of the deuterium signal. This suggests that a strong percolation has occurred at $5.4 \mathrm{~m}$ which is responsible for obliterating the isotope record (Schwikowski and others, 2006).

All the chemical species $\left(\mathrm{Cl}^{-}, \mathrm{Na}^{+}, \mathrm{Mg}^{2+}, \mathrm{K}^{+}, \mathrm{SO}_{4}{ }^{2-}\right.$, $\mathrm{NO}_{3}{ }^{-}$and $\mathrm{NH}_{4}{ }^{+}$) show fluctuations throughout their profiles (Fig. 6). Nevertheless, there is no obvious correlation of these fluctuations with seasonal layers interpreted from 


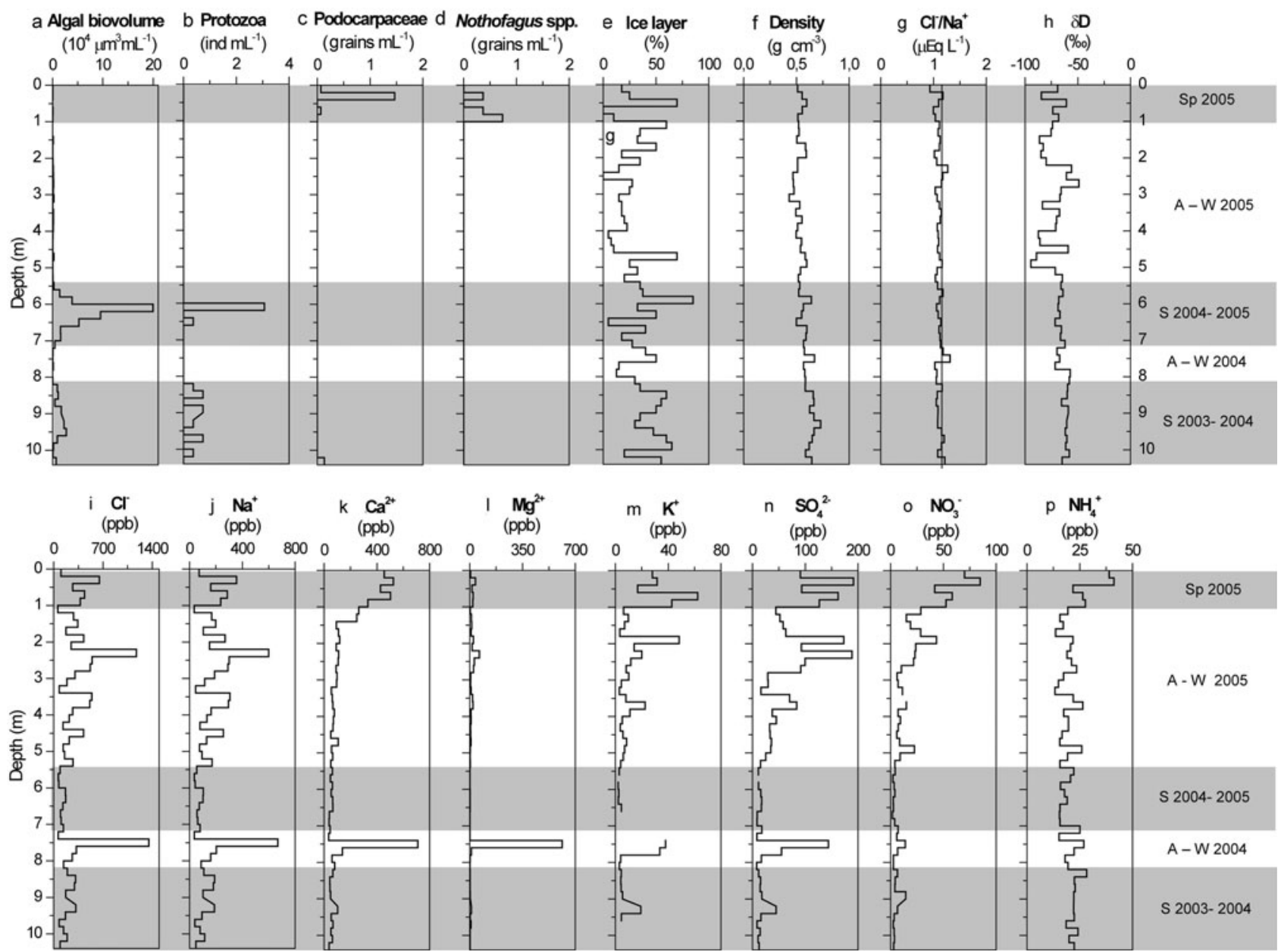

Fig. 5. Profiles of the Volcán Osorno core: (a) algal biovolume; (b) protozoa abundance; (c) Podocarpacea pollen concentration; (d) Nothofagus spp. pollen concentration; (e) ice-layer percentage; (f) firn density; (g) $\mathrm{Cl}^{-} / \mathrm{Na}^{+}$ratio (vertical line corresponds to the marine reference (Keene and others, 1986)); (h) deuterium; (i) chloride; (j) sodium; (k) calcium; (I) magnesium; (m) potassium; (n) sulphate; (o) nitrate; and (p) ammonium. The lower grey shaded areas indicate the algal growth periods (summer: S) estimated from microalgal peaks. The upper grey shaded area indicates the pollen flowering period (spring: Sp) estimated from pollen peaks. The autumn-winter periods (in white) are labelled A-W.

biological profiles. What is clear is that all chemical species exhibit concentrations that tend to zero at the deepest layers (9.2-10.4 m), suggesting that meltwater percolation is responsible for destroying the signals at depth. In the case of the periods corresponding to autumn-winter 2002-03, a

Table 4. Ion median concentrations of all samples in the Volcán Mocho-Choshuenco summit core

Median

$\mu \mathrm{EqL} \mathrm{L}^{-1}$

$\begin{array}{ll}\begin{array}{ll}\text { Anions } \\ \mathrm{Cl}^{-}\end{array} & \\ \mathrm{SO}_{4}{ }^{2-} & 3.05 \\ \mathrm{NO}_{3}{ }^{-} & 0.91 \\ \text { Cations } & 0.24 \\ \mathrm{Na}^{+} & \\ \mathrm{Ca}^{2+} & 3.03 \\ \mathrm{NH}_{4}{ }^{+} & 1.86 \\ \mathrm{Mg}^{2+} & 1.06 \\ \mathrm{~K}^{+} & 0.50 \\ & 0.14\end{array}$

maximum signal of $\mathrm{Na}^{+}, \mathrm{Mg}^{2+}, \mathrm{K}^{+}$and $\mathrm{SO}_{4}{ }^{2-}$ concentrations is observed, with a minimum in the summers of 2002/03 and 2003/04, similar to the case of Volcán Osorno. However, this is not true for summer 2004/05, autumn-winter 2004 and summer 2001/02, possibly because of strong percolation that can cause a migration of chemical species to deeper layers and in this manner obliterate the seasonal signal. The relevance of the melt process is illustrated by the thin layers which are seen to correspond to the periods interpreted as summer.

Main atmospheric sources of chemical trace species Similar to the case of Volcán Osorno, the site is characterized by the dominance of natural constituents, indicated by the $\mathrm{Cl}^{-}$and $\mathrm{Na}^{+}$concentrations recorded throughout the core (Table 4). Sea-spray contribution of chemical species is important at this site, as demonstrated by (1) the high correlation coefficient between $\mathrm{Cl}^{-}$and $\mathrm{Na}^{+}(r=0.90$; Table 5); (2) the proximity of the $\mathrm{Cl}^{-} / \mathrm{Na}^{+}$ratio (Fig. $6 \mathrm{~g}$ ) to the marine reference value of 1.16 (Keene and others 1986; Schwikowski and others 1999b) in the upper $6 \mathrm{~m}$. Below $6.6 \mathrm{~m}$ the $\mathrm{Cl}^{-} / \mathrm{Na}^{+}$ratio deviates substantially from the marine reference value, which suggests a strong elution due to strong percolation at this site (Davies and others, 1982; 


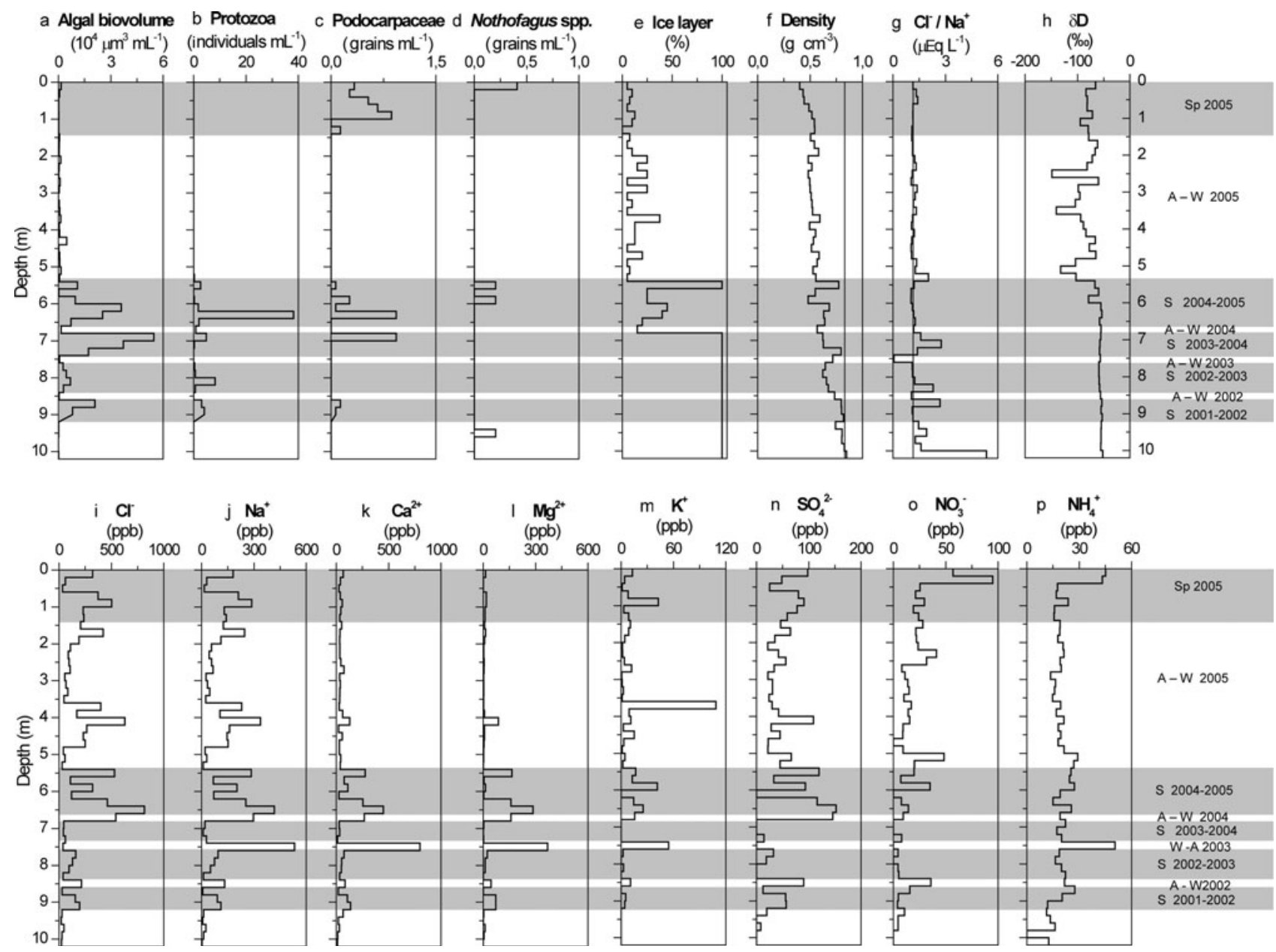

Fig. 6. Same as Figure 5, but for the Volcán Mocho-Choshuenco summit core.

Shiraiwa and others, 2002); and (3) the fact that other related sea-salt constituents such as $\mathrm{Cl}^{-}, \mathrm{Na}^{+}, \mathrm{Ca}^{2+}$ and $\mathrm{Mg}^{2+}$ (Table 5) show high correlation coefficients at this site (Watanabe and others, 2003). As in the Volcán Osorno ice core, the marine origin can be explained by the proximity of the site to the Pacific Ocean $(\sim 100 \mathrm{~km})$ and the prevailing westerly circulation.

\section{Estimation of mass balance}

Density data indicate that this $10.2 \mathrm{~m}$ long core is equivalent to $6.16 \mathrm{~m}$ w.e. According to the analysis of biological profiles in combination with the ice-layer information and deuterium, it is estimated that three annual layers are preserved (2002/03-2003/04-2004/05), in addition to the last accumulation period (winter-autumn 2005). The net mass balance is $0.66 \mathrm{~m}$ w.e. for $2002 / 03,0.56 \mathrm{~m}$ w.e. for 2003/04, and $0.86 \mathrm{~m}$ w.e. for 2004/05, with a mean annual (early-autumn to early-autumn) net mass balance from 2003 to 2005 of $0.69 \pm 0.15 \mathrm{~m}$ w.e. for this site. The winter 2005 balance is $2.12 \mathrm{~m}$ w.e.

In 2003 a mass-balance programme was initiated on the southeastern glacier of Volcán Mocho-Choshuenco, calculating the net mass balance for the period 2003/04 based on the stake method (Rivera and others, 2005). The summit stake was frequently lost due to strong winds, with the closest stake (No. 21) being located at $2169 \mathrm{~m}$ a.s.l. At stake 21 the annual mass balance was $0.9 \mathrm{~m}$ w.e. and the winter balance was $2.4 \mathrm{~m}$ w.e. (Rivera and others, 2005), in good agreement with the mass-balance values of $0.69 \mathrm{~m}$ w.e. and $2.12 \mathrm{~m}$ w.e. estimated from the summit core for 2005 . These results demonstrate the robustness of the multi-proxy dating method including biological, physical and chemical parameters as presented in this study.

\section{Volcán Mocho-Choshuenco 2000 m a.s.I. core analysis}

One firn layer of $8.4 \mathrm{~m}$ depth was observed at this site, which is interpreted as corresponding to autumn-winter 2005. An ice layer was detected (Fig. 7) below the firn down to the bottom of the core $(10 \mathrm{~m})$. Therefore the $8.4 \mathrm{~m}$ depth corresponds to the firn-ice interface. During the drilling (26 October 2005), the firn was saturated with water at the

Table 5. Correlation matrix of the chemical species from the Volcán Mocho-Choshuenco summit core. For more details see Table 3

\begin{tabular}{lccccccc}
\hline & $\mathrm{Cl}^{-}$ & $\mathrm{Na}^{+}$ & $\mathrm{Ca}^{2+}$ & $\mathrm{Mg}^{2+}$ & $\mathrm{K}^{+}$ & $\mathrm{SO}_{4}{ }^{2-}$ & $\mathrm{NO}_{3}{ }^{-}$ \\
\hline $\mathrm{Na}^{+}$ & $\frac{\mathbf{0 . 9 0}}{0.51}$ & 0.67 & & & & & \\
$\mathrm{Ca}^{2+}$ & 0.67 & $\mathbf{0 . 8 0}$ & $\mathbf{0 . 8 4}$ & & & & \\
$\mathrm{Mg}^{2+}$ & 0.67 & 0.56 & & & \\
$\mathrm{~K}^{+}$ & 0.62 & $\mathbf{0 . 7 9}$ & 0.58 & 0.69 & 0.63 & & \\
$\mathrm{SO}_{4}{ }^{2-}$ & $\mathbf{0 . 7 4}$ & $\mathbf{0 . 7 2}$ & $\mathbf{0 . 7 3}$ & 0.69 & & \\
$\mathrm{NO}_{3}{ }^{-}$ & 0.17 & 0.18 & -0.06 & -0.13 & 0.12 & 0.34 & \\
$\mathrm{NH}_{4}{ }^{+}$ & 0.07 & 0.26 & 0.34 & 0.13 & 0.39 & 0.30 & 0.56 \\
\hline
\end{tabular}




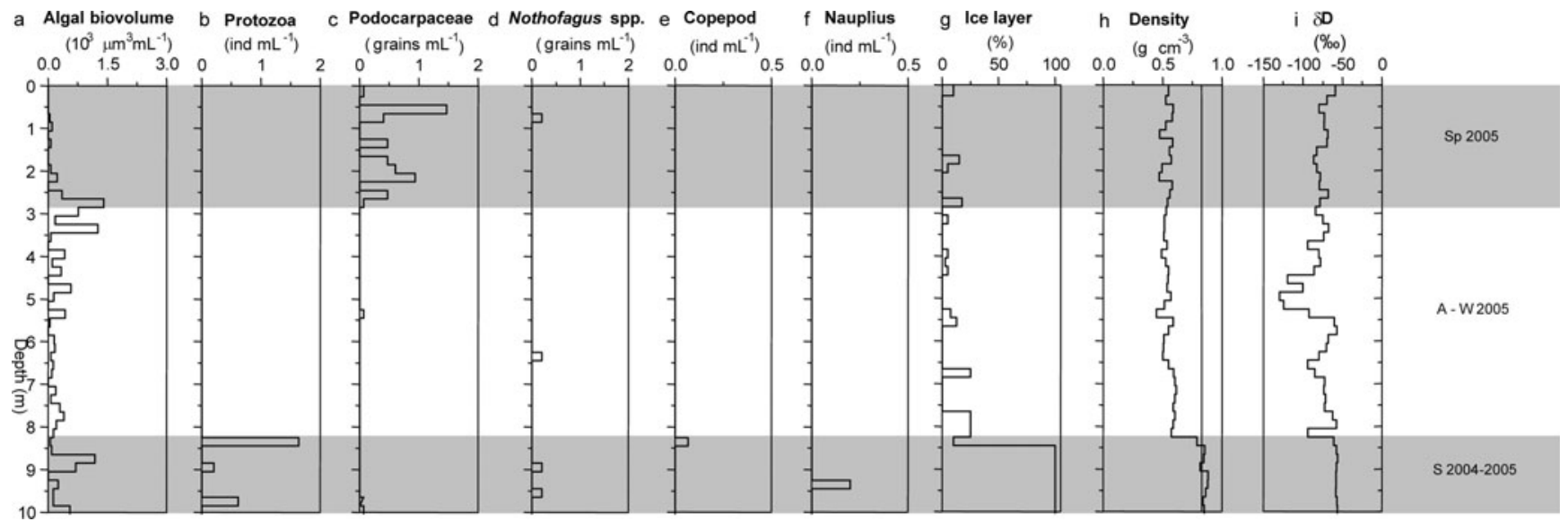

Fig. 7. Profiles of the ice core from Volcán Mocho-Choshuenco at $2000 \mathrm{~m}$ a.s.l.: (a) algal biovolume; (b) protozoa abundance; (c) Podocarpacea pollen concentration; (d) Nothofagus spp. pollen concentration; (e) copepod abundance; (f) nauplius (larval stage of copepod); (g) ice-layer percentage; (h) firn density (vertical line corresponds to the firn/ice transition value of $0.83 \mathrm{~g} \mathrm{~cm}^{-3}$ (Paterson, 1994)); and (i) deuterium. The lower grey shaded area indicates the lower ice layer, estimated to correspond to the 2004/05 summer period (S) and older ice. The upper grey shaded area indicates the pollen flowering period (spring: Sp) estimated from pollen peaks. The autumn-winter period (in white) is labelled A-W.

firn-ice interface. A water-saturated layer at the firn-ice transition has been commonly found at other temperate glaciers such as Glaciar San Rafael (Yamada, 1987) and Glaciar Tyndall (Shirawa and others, 2002) in Patagonia.

The $\delta \mathrm{D}$ values are observed to fluctuate in the firn layer (Fig. 7), with a dampening of the signal below that depth. This indicates that the winter-autumn 2005 signal is still preserved, whereas the signal at depth, corresponding to summer 2004/05, is obliterated by meltwater percolation. Microalgal biovolume and pollen concentrations are very small at Volcán Mocho-Choshuenco at 2000 ma.s.l. compared to the values found in the cores drilled at the summits of Mocho-Choshuenco and Volcán Osorno, and are negligible in the ice layer corresponding to summer 2004/05. These biological components are believed to be washed out by strong melt and percolation. It is suggested that the algal biovolume values in this core originate from algal transportation by wind from their source during autumn-winter. In contrast, protozoa, copepods and nauplius are preserved within the summer 2004/05 ice layer (Fig. 7). A surface signal between 0 and $2.8 \mathrm{~m}$ is observed in the Podocarpaceae pollen profile, which is interpreted as corresponding to spring 2005.

\section{Estimation of mass balance}

Density profile data indicate that the $10.0 \mathrm{~m}$ long core corresponds to $6.0 \mathrm{~m}$ w.e. According to the profiles of protozoa, copepod, nauplius, pollen, ice layers and deuterium, the core is interpreted as including a $2.95 \mathrm{~m}$ w.e. layer from the last accumulation period (autumn-winter) and an underlying ice layer with no indication of an older annual or seasonal transition. The $2.95 \mathrm{~m}$ w.e. winter balance is in good agreement with the winter balance of $2.9 \mathrm{~m}$ w.e. estimated by Rivera and others (2005) from stake measurements made in 2003 at the same site (stake 18).

\section{CONCLUSIONS}

In all cores, seasonal cycles in deuterium are dampened substantially by meltwater percolation below the last autumn-winter accumulation layer. This is consistent with a sudden increase in firn density and also with the presence of ice layers within the cores.

The $\mathrm{Cl}^{-} / \mathrm{Na}^{+}$ratio and the high correlation of sea-salt constituents indicate that marine contribution is the main source of these species. This is reasonable considering the proximity of the core sites $(\sim 100 \mathrm{~km})$ to the Pacific Ocean and the prevailing westerly circulation. At the highest site (Volcán Osorno), some chemical species $\left(\mathrm{Cl}^{-}, \mathrm{K}^{+}, \mathrm{Na}^{+}\right.$and $\mathrm{SO}_{4}{ }^{2-}$ ) show seasonal variations. Based on the large concentration values of these species found within the surface layer (spring 2005) and the presence of abundant ice layers within the summer snow and firn, this suggests that partial percolation is the most probable cause for seasonality. Other species at Volcán Osorno $\left(\mathrm{NO}_{3}{ }^{-}\right.$and $\left.\mathrm{NH}_{4}{ }^{+}\right)$ show no seasonal variations, suggesting that they are more affected by melt and percolation which obliterates the signal. At the summit of Volcán Mocho-Choshuenco, the chemical species show no clear seasonality, indicating that melt and percolation are more relevant at this site.

Microalgae, protozoa, copepod and pollen show clear seasonal cycles in the summit cores. Maximum values of microorganisms are interpreted as corresponding to the summer melt season, when the presence of meltwater favours their growth. Maximum levels of pollen occur in the spring, which corresponds to the flowering period of tree species in the surrounding Valdivian forest at lower altitudes. At the lowest site, Volcán Mocho-Choshuenco $(2000 \mathrm{~m})$, the microalgae values are very small throughout the core. Within the ice layer at depth, microalgae and pollen records do not show maximum values as might be expected from the data observed in the summit cores, suggesting that they are strongly affected by melt and percolation, as evidenced by a water table detected at $8.4 \mathrm{~m}$ depth at the firn-ice transition.

From the biological, physical and chemical records, the following interpretations are derived: the core from Volcán Osorno presents an annual layer (2004/05) and a layer from the last accumulation period (winter-autumn 2005); the core from Volcán Mocho-Choshuenco drilled at the summit presents three annual layers (2002/03-2003/04-2004/05), plus a layer from the last accumulation period (winter- 
autumn 2005). The core from Volcán Mocho-Choshuenco drilled at 2000 ma.s.l. only presents one layer, corresponding to the last accumulation period (winter-autumn 2005). Winter and net mass-balance estimations of ice cores from Volcán Mocho-Choshuenco are in good agreement with values previously obtained by means of the stake method in the period 2003/04 (Rivera and others, 2005).

The microorganisms and pollen are therefore useful seasonal markers for ice-core dating and reconstruction of past annual mass balance in temperate glaciers located in the Chilean lake district. This is especially important considering that at these sites stable-isotope and chemicalspecies records are destroyed by meltwater percolation.

\section{ACKNOWLEDGEMENTS}

This work was supported by Fondo Nacional de Ciencia y Tecnología of Chile (FONDECYT 1040989 and 1061269) and Centro de Estudios Científicos (CECS). The CECS is funded by the Chilean Government through the Millennium Science Initiative and the Centers of Excellence Base Financing Program of CONICYT (Comisión Nacional de Investigación Cientifica y Technológica de Chile). CECS is also supported by a group of private companies which at present includes Antofagasta Minerals, Arauco, Empresas CMPC, Indura, Naviera Ultragas and Telefónica del Sur. We acknowledge field support from G. Campos, D. Schwerer, R. Mella, M. Rodríguez and M. Arévalo. We thank R. Silva (Universidad Austral) for the scanning electron microscope imagery, P. Moreno (Universidad de Chile) for advice on pollen identification, and $R$. Jorquera and $H$. Silva for collaboration at CECS.

\section{REFERENCES}

Alley, R.B., A.J. Gow, S.J. Johnsen, J. Kipfstuhl, D.A. Meese and T. Thorsteinsson. 1995. Comparison of deep ice cores. Nature, 373(6513), 393-394.

Bourgeois, J., R. Koerner, K. Gajewski and D. Fisher. 2000. A Holocene ice-core pollen record from Ellesmere Island, Nunavut, Canada. Quat. Res., 54(2), 275-283.

Davies, T.D., C.E. Vincent and P. Brimblecombe. 1982. Preferential elution of strong acids from a Norwegian ice cap. Nature, 300(5888), 161-163.

Echegaray, J. 2005. Evolución geológica y geoquímica del centro volcánico Mocho-Choshuenco, Andes del Sur, $40^{\circ} \mathrm{S}$. (MSc thesis, Universidad de Chile.)

Eichler, A., M. Schwikowski and H.W. Gäggeler. 2001. Meltwaterinduced relocation of chemical species in Alpine firn. Tellus, 53B(2), 192-203.

Eichler, A., M. Schwikowski, M. Furger, U. Schotterer and H.W. Gäggeler. 2004. Sources and distribution of trace species in Alpine precipitation inferred from two 60-year ice core paleorecords. Atmos. Chem. Phys. Discuss., 4(1), 71-108.

González-Ferrán, O. 1995. Volcanes de Chile. Santiago, Instituto Geográfico Militar.

Hechenleitner, V. and 6 others. 2005. Plantas amenazadas del Centro-Sur de Chile: distribución, conservación y propagación. Santiago, Universidad Austral de Chile y Real Jardín Botánico de Edimburgo.

Heusser, C. 1971. Pollen and spores of Chile: modern types of the Pteridophyta, Gymnospermae and Angiospermae. Tucson, AZ, University of Arizona Press.

Hillebrand, H., C. Dürselen, D. Kirschstel, U. Pollingher and T. Zohary. 1999. Biovolume calculation for pelagic and benthic Microalgae. J. Phycol., 35(2), 403-424.
Keene, W.C., A.A.P. Pszenny, J.N. Galloway and M.E. Hawley. 1986. Sea-salt corrections and interpretation of constituent ratios in marine precipitation. J. Geophys. Res., 91(D6), 6647-6658.

Kikuchi, Y. 1994. Glaciella, a new genus of freshwater Canthyocamyidae (Copepoda Harpacticoida) from a glacier in Nepal, Himalayas. Hydrobiologia, 292/293, 59-66.

Kohshima, S. 1984. A novel cold-tolerant insect found in a Himalayan glacier. Nature, 310(5974), 225-227.

Kohshima, S. 1987. Glacial biology and biotic communities. In Kawano, S., J.H. Connell and T. Hidaka, eds. Evolution and coadaptation in biotic communities. Kyoto, Kyoto University. Faculty of Science, 77-92.

Kohshima, S., Y. Yoshimura and N. Takeuchi. 2002. Glacier ecosystem and biological ice-core analysis. In Casassa, G., F. Sepúlveda and R. Sinclair, eds. The Patagonian ice fields: a unique natural laboratory for environmental and climate change studies. New York, Kluwer Academic/Plenum Publishers, 1-8.

Kohshima, S. and 7 others. 2007. Estimation of net accumulation rate at a Patagonian glacier by ice core analyses using snow algae. Global Planet. Change, 59(1), 236-244.

Liu, K.B., Z. Yao and L.G. Thompson. 1998. A pollen record of Holocene climatic changes from the Dunde ice cap, QinghaiTibetan Plateau. Geology, 26(2), 135-138.

Lohmann, H. 1908. Untersuchungen zur Festellung des vollständigen Gehaltes des Meeres an Plankton. Wiss. Meeresunters. Kiel, 10, 131-370.

McManus, J.F. 2004. A great grand-daddy of ice cores. Nature, 429(6992), 611-612.

Müller, T., T. Leya and G. Fuhr. 2001. Persistent snow algal fields in Spitsbergen: field observations and a hypothesis about the annual cell circulation. Arct. Antarct. Alp. Res., 33(1), 42-51.

Nakazawa, F. and 8 others. 2004. Application of pollen analysis to dating of ice cores from lower-latitude glaciers. J. Geophys. Res., 109(F4), F04001. (10.1029/2004JF000125.)

Nakazawa, F. and 6 others. 2005. Dating of seasonal snow/firn accumulation layers using pollen analysis. J. Glaciol., 51(174), 483-490.

Olivier, S. and 10 others. 2003. Glaciochemical investigation of an ice core from Belukha Glacier, Siberian Altai. Geophys. Res. Lett., 30(19), 2019. (10.1029/2003GL018290.)

Paterson, W.S.B. 1994. The physics of glaciers. Third edition. Oxford, etc., Elsevier.

Pohjola, V.A. 2002. On the potential to retrieve climatic and environmental information from ice core sites suffering periodic melt, with specific assessment of the Southern Patagonia Ice Field. In Casassa, G., F. Sepúlveda and R. Sinclair, eds. The Patagonian ice fields: a unique natural laboratory for environmental and climate change studies. New York, Kluwer Academic/Plenum Publishers, 125-138.

Reese, C.A. and K.B. Liu. 2005. Interannual variability in pollen dispersal and deposition on the tropical Quelccaya ice cap. Prof. Geogr., 57(2), 185-197.

Reese, C.A., K.B. Liu and K.R. Mountain. 2003. Pollen dispersal and deposition on the ice cap of Mt. Parinacota, southwestern Bolivia. Arct. Antarct. Alp. Res., 35(4), 469-474.

Rivera, A., F. Bown, G. Casassa, C. Acuña and J. Clavero. 2005. Glacier shrinkage and negative mass balance in the Chilean Lake District $\left(40^{\circ}\right.$ S). Hydrol. Sci. J., 50(6), 963-974.

Riveros, M. and C. Smith-Ramirez. 1995. Patrones de floración y fructificación en bosques del sur de Chile. In Armesto, J., C. Villagrán and M.T.K. Arroyo, eds. Ecología de los bosques nativos de Chile. Santiago, Editorial Universitaria, 235-249.

Riveros, M., B. Palma, S. Erazo and S. O'Reilly. 1995. Fenelogía y flujo de polen en especies del género Nothofagus. Bot. Exp., 57(1), 45-54.

Riveros, M., M. Pérez, P. Báez and A. Báez. 2003. Cinética mensual de parámetros químicos en la fase de prefloración en especies del género Nothofagus. Bosque, 24(3), 85-95. 
Santibáñez, P. 2007. Análisis biológico en testigos de neviza/hielo en los glaciares del volcán Osorno (X Región de Los Lagos, Chile). (Undergraduate thesis, Universidad Austral de Chile.)

Schwikowski, M., A. Döscher, H. Gäggeler and U. Schotterer. 1999a. Anthropogenic versus natural sources of atmospheric sulphate from an Alpine ice core. Tellus, 51B(5), 938-951.

Schwikowski, M., S. Brütsch, H.W. Gäggeler and U. Schotterer. 1999b. A high-resolution air chemistry record from an Alpine ice core: Fiescherhorn glacier, Swiss Alps. J. Geophys. Res., 104(D11), 13,709-13,719.

Schwikowski, M., S. Brütsch, G. Casassa and A. Rivera. 2006. A potential high-elevation ice-core site at Hielo Patagónico Sur. Ann. Glaciol., 43, 8-13.

Segawa, T., K. Miyamoto, K. Ushida, K. Agata, N. Okada and S. Kohshima. 2005. Seasonal change in bacterial flora and biomass in mountain snow from the Tateyama Mountains, Japan, analyzed by $16 \mathrm{~S}$ rRNA gene sequencing and real-time PCR. Appl. Environ. Microbiol., 71(1), 123-130.

Shiraiwa, T. and 6 others. 2002. High net accumulation rates at Campo de Hielo Patagónico Sur, South America, revealed by analysis of a $45.97 \mathrm{~m}$ long ice core. Ann. Glaciol., 35, 84-90.

Takeuchi, N. 2001. The altitudinal distribution of snow algae on an Alaska glacier (Gulkana Glacier in the Alaska Range). Hydrol. Process., 15(18), 3447-3459.

Takeuchi, N. and S. Kohshima. 2004. A snow algal community on a Patagonian glacier, Tyndall glacier in the Southern Patagonia Icefield. Arct. Antarct. Alp. Res., 36(1), 91-98.
Takeuchi, N., S. Kohshima and K. Fujita. 1998. Snow algae community on a Himalayan glacier, Glacier AX010 East Nepal: relationship with glacier summer mass balance. Bull. Glacier Res. 16, 43-50.

Thompson, L.G., E. Mosley-Thompson and K.A. Henderson. 2000. Ice-core palaeoclimate records in tropical South America since the Last Glacial Maximum. J. Quat. Sci., 15(4), 377-394.

Thompson, L.G., E. Mosley-Thompson, M.E. Davis, P.N. Lin, K. Henderson and T.A. Mashiotta. 2003. Tropical glacier and ice core evidence of climate change on annual to millennial time scales. Climatic Change, 59(1-2), 137-155.

Uetake, J. and 7 others. 2006. Biological ice-core analysis of Sofiyskiy glacier in the Russian Altai. Ann. Glaciol., 43, 70-78.

Watanabe, O. and 10 others. 2003. General tendencies of stable isotopes and major chemical constituents of the Dome Fuji deep ice core. Mem. Nat. Inst. Polar Res., 57, 1-24.

Yamada, T. 1987. Glaciological characteristics revealed by 37.6-m deep core drilled at the accumulation area of San Rafael Glacier, the Northern Patagonia Icefield. Bull. Glacier Res. 4 59-67.

Yoshimura, Y., S. Kohshima and S. Ohtani. 1997. A community of snow algae on a Himalayan glacier: change of algal biomass and community structure with altitude. Arct. Alp. Res., 29(1), 126-137.

Yoshimura, Y., S. Kohshima, N. Takeuchi, K. Seko and K. Fujita. 2000. Himalayan ice-core dating with snow algae. J. Glaciol., 46(153), 335-340.

MS received 29 November 2007 and accepted in revised form 9 March 2008 